\title{
Expanded description of Lamproglena monodi (Copepoda: Lernaeidae), parasitizing native and introduced fishes in Brazil
}

\author{
Descrição expandida de Lamproglena monodi (Copepoda: Lernaeidae), \\ parasita de peixes nativos e introduzidos no Brasil \\ Rodney Kozlowiski de Azevedo ${ }^{1}$; Vanessa Doro Abdallah ${ }^{1}$; Reinaldo José da Silva ${ }^{1}$;
Tatiana M. Pegado de Azevedo ${ }^{2}$ Maurício Laterça Martins ${ }^{3}$; José Luis Luque ${ }^{4 *}$
}

${ }^{1}$ Departamento de Parasitologia, Instituto de Biociências, Universidade Estadual Paulista “Júlio de Mesquita Filho" - UNESP, Botucatu, SP, Brasil

${ }^{2}$ Programa de Pós-graduação em Ciência Animal nos Trópicos, Universidade Federal da Bahia - UFBA, Salvador, BA, Brasil

${ }^{3}$ Laboratório AQUOS - Sanidade de Organismos Aquáticos, Departamento de Aquicultura, Centro de Ciências Agrárias, Universidade Federal de Santa Catarina - UFSC, Florianópolis, SC, Brasil

${ }^{4}$ Departamento de Parasitologia Animal, Universidade Federal Rural do Rio de Janeiro - UFRRJ, Seropédica, RJ, Brasil

Received November 8, 2011

Accepted April 4, 2012

\begin{abstract}
An occurrence of the copepod Lamproglena monodi Capart, 1944, parasitizing freshwater fishes in Brazil is presented, along with new morphological data. This crustacean was originally described parasitizing several cichlids in Africa. In the present study, the crustaceans were collected from the body surface and gills of two fish species native to Brazil [Astronotus ocellatus (Agassiz, 1831) and Cichla ocellaris Bloch and Schneider, 1801] and two introduced species [Oreochromis niloticus (Linnaeus, 1758) and Tilapia rendalli (Boulenger, 1897)]. The Brazilian specimens exhibited some morphometric intraspecies differences in relation to the specimens from Congo-Kinshasa and Egypt.

Keywords: Lamproglena monodi, Astronotus ocellatus, Cichla ocellaris, Oreochromis niloticus, Tilapia rendalli, Brazil.
\end{abstract}

\section{Resumo}

A ocorrência e novos dados morfológicos do copépode Lamproglena monodi Capart, 1944 parasitando peixes dulcícolas no Brasil são apresentados. Este crustáceo foi originalmente descrito parasitando vários ciclídeos da África. No presente trabalho, os crustáceos foram coletados das brânquias e superfície do corpo dos peixes nativos do Brasil [Astronotus ocellatus (Agassiz, 1831) e Cichla ocellaris Bloch e Schneider, 1801 e duas espécies introduzidas Oreochromis niloticus (Linnaeus, 1758) e Tilapia rendalli (Boulenger, 1897)]. Os espécimes coletados no Brasil apresentaram algumas diferenças morfométricas intraespecíficas em relação aos espécimes do Congo-Kinshasa e Egito.

Palavras-chave: Lamproglena monodi, Astronotus ocellatus, Cichla ocellaris, Oreochromis niloticus, Tilapia rendalli, Brasil.

\section{Introduction}

The introduction of non-native species into ecosystems may influence organic communities by changing species diversity (MACK et al., 2000). Parasites may have considerably greater impact on the interactions of native animal communities during invasions than previously acknowledged (TARASCHEWSKI, 2006).

\footnotetext{
*Corresponding author: José Luis Luque

Departamento de Parasitologia Animal, Universidade Federal Rural do Rio de Janeiro - UFRRJ, CP 74.508, CEP 23851-970, Seropédica, RJ, Brasil

e-mail: jlluque@ufrrj.br
}

Copepods are a common component of the ectoparasite assemblages of all kinds of fishes, from all environments and ecosystems (BOXSHALL; HALSEY, 2004). In the Neotropics, copepods are the second largest group of parasites in marine fish and the third largest in freshwater hosts (LUQUE; TAVARES, 2007).

Lamproglena monodi has been described parasitizing the gills of Serranochromis thumbergi, Haplochromis macrops, Haplochromis eduardii, H. moffati, H. serridens and H. fasciatus in Pweto, Lac Moreo, Katanga, Democratic Republic of the Congo (CAPART, 1944). This species was later re-described parasitizing the gills of 
Oreochromis niloticus niloticus, Sarotherodon galilaeus and Tilapia zilli in Egypt (see IBRAHEEM; IZAWA, 2000).

The following diagnostic characteristics were used by Capart (1944) to described L. monodi: body elongated, abdomen longer than wide, antennule bi-segmented, basal segment very wide and ornamented, maxilla robust and truncated, claw sharp and curved, four pairs of biramous legs and a fifth leg pair smaller and apparently atrophied, abdomen with three segments poorly distinguished and caudal rami forked. Recently, this species was redescribed by Ibraheem and Izawa (2000). However, an analysis on these two studies reveals some intraspecies differences in relation to the specimens collected in Brazil. Azevedo et al. (2010) and Martins et al. (2010) recorded this species as Lamproglena sp., respectively, in Guandu River, state of Rio de Janeiro and in the state of Santa Catarina, Brazil.

In the present study, the species $L$. monodi was examined. This species seems to have been introduced into Brazil simultaneously with its hosts. Comments are made regarding differences observed between the specimens collected in Brazil and the specimens described by Capart (1944) and redescribed by Ibraheem and Izawa (2000). Electron microscope observations were made.

\section{Materials and Methods}

Between December 2004 and August 2009, 35 specimens of oscar fish (Astronotus ocellatus), 26 specimens of peacock bass (Cichla ocellaris) and 30 specimens of redbreast tilapia (Tilapia rendalli) were collected from the Guandu River $\left(22^{\circ} 48^{\prime} 32^{\prime \prime} S\right.$ and $43^{\circ} 37^{\prime} 35^{\prime \prime}$ W), state of Rio de Janeiro. In addition, between August 2003 and July 2004, 360 Nile tilapia (Oreochromis niloticus) from Nova Trento ( $27^{\circ} 17^{\prime} 09^{\prime \prime} \mathrm{S}$ and $\left.48^{\circ} 02 ; 55^{\prime} 47^{\prime \prime} \mathrm{W}\right)$, and between October 2004 and June 2005137 Nile tilapia from Blumenau $\left(26^{\circ} 55^{\prime} 10^{\prime \prime} \mathrm{S}\right.$ and $\left.49^{\circ} 03^{\prime} 58^{\prime \prime} \mathrm{W}\right)$, Ituporanga (27 $24^{\prime} 52^{\prime \prime} \mathrm{S}$ and $\left.49^{\circ} 36^{\prime} 09^{\prime \prime} \mathrm{W}\right)$ and Joinville ( $26^{\circ} 18^{\prime} 16^{\prime \prime} \mathrm{S}$ and $\left.48^{\circ} 50^{\prime} 44^{\prime \prime} \mathrm{W}\right)$, state of Santa Catarina, were studied for ectoparasites.

The fish were collected by using a fishing rod and cast nets and were identified in accordance with Britski et al. (2007). Any crustaceans present were removed from the body surface and gills and fixed in $70 \%$ ethanol. In the laboratory, some specimens were transferred to lactic acid and were used for drawings. Other specimens were prepared for scanning electron microscopy using standard techniques (DEDAVID et al., 2007) and were analyzed using a FEI Quanta 200 scanning electron microscope at the Electron Microscopy Center of the Institute of Biosciences, UNESP, Botucatu campus. Differential interference contrast microscopy (Leica DMLB 5000) was used for the morphological examination. Twenty specimens were used for measurements: three from Astronotus ocellatus, three from Cichla ocellaris, five from Tilapia rendalli and nine from Oreochromis niloticus. Measurements (in millimeters) were expressed as means followed by the range in parentheses. The illustrations were produced with the aid of a camera lucida mounted on a Leica DMLS microscope. Voucher specimens were deposited in the collection of the Institute of Biosciences of Botucatu (CHIBB), Botucatu, SP, Brazil.

\section{Results}

\section{Lamproglena monodi Capart, 1944}

Female. Description (Figures 1-4) (Based on 20 specimens) Body elongated, $3.6(3.0-4.2 ; \mathrm{n}=20)$ in length. Cephalothorax 0.6 in width $(0.5-0.7 ; n=20), 18.8 \%$ of entire body length; dorsal surface flat, ventral surface with two rounded lobes on margin posterior to level of base of first pair of legs. Thorax with three pedigerous somites, segmentation poorly marked: first with width of 0.6 $(0.5-0.7 ; \mathrm{n}=20)$, second segment width of $0.7(0.5-0.75 ; \mathrm{n}=20)$ and third segment width of $0.75(0.6-0.85 ; \mathrm{n}=20)$, increasing in diameter posteriorly. Genital somite width $0.5(0.4-0.65 ; \mathrm{n}=20)$, separated from body by a constriction. Orifices of oviduct situated dorsolaterally; eggs in uniserial sequence, extending twice the length of the abdomen, containing a sequence of 28 eggs (25-30). Abdomen trisegmented, 1.2 in length $(1.0-1.8 ; \mathrm{n}=20), 0.3$ in width $(0.2-0.4 ; n=20), 33.3 \%$ of entire body length. Caudal ramus forked, fused with abdomen; inner ramus conical, terminated with three short papillae, and outer ramus sharp and longer than inner ramus. Uniramous antenna, trisegmented; basal segment broad, segments progressively smaller, distal segment terminating with four setae of different sizes. Antennule uniramous, bisegmented; basal segment very wide, with 17 setae, and distal segment rounded, with nine setae of different sizes. Oral region on anterior quarter of cephalothorax. Maxilla robust, truncated, terminated with claw sharp and curved. Maxilliped bisegmented; base broad, second segment turned toward interior, terminating in three claws. Four pairs of legs, biramous, dissimilar; exopods larger than endopods, both bisegmented; exopods of first pair of legs terminating in four setae, those of second pair of legs terminating in three setae and those of third and fourth pairs of legs terminating in two setae; endopods of first, third and fourth pairs of legs terminating in four setae and those of second pair of legs terminating in three setae. Base of exopods of all legs with a single seta. Fifth pair of legs rudimentary.

Male: unknown.

\section{Taxonomic summary}

Hosts: Astronotus ocellatus (Agassiz, 1831), Cichla ocellaris Bloch and Schneider, 1801, Oreochromis niloticus (Linnaeus, 1758) and Tilapia rendalli (Boulenger, 1897)

Localities: Guandu River, state of Rio de Janeiro; Nova Trento, Blumenau, Ituporanga and Joinville, state of Santa Catarina, Brazil.

Site of infestation: Gills and body surface

Voucher specimens: CHIBB No 6722 (fourteen females).

\section{Discussion}

The species described in the present paper was identified as L. monodi because it exhibited the characteristics used by Capart (1944) in the original description. The specimens collected from the different localities and hosts showed similar morphometric characteristics. 

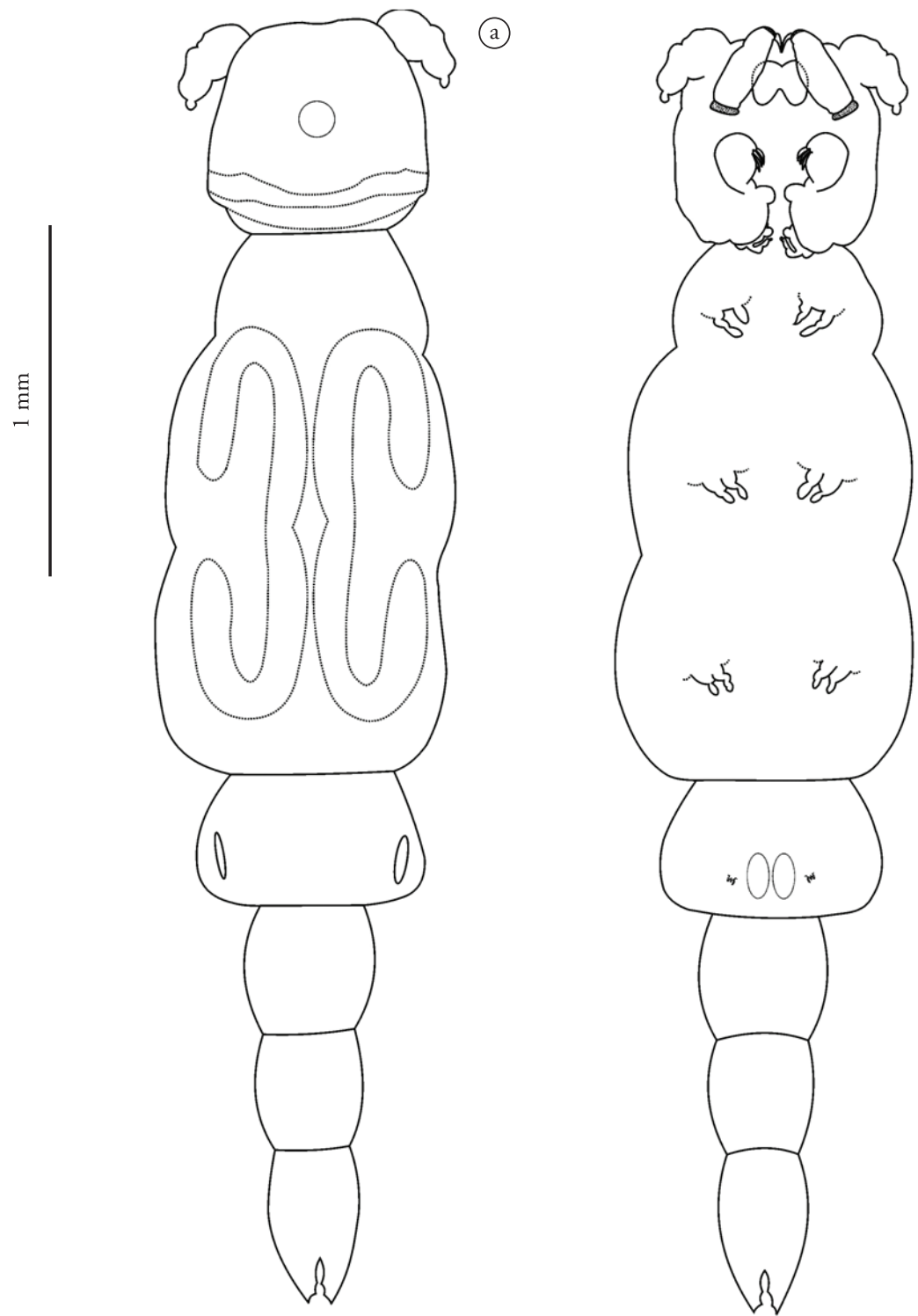

(b)

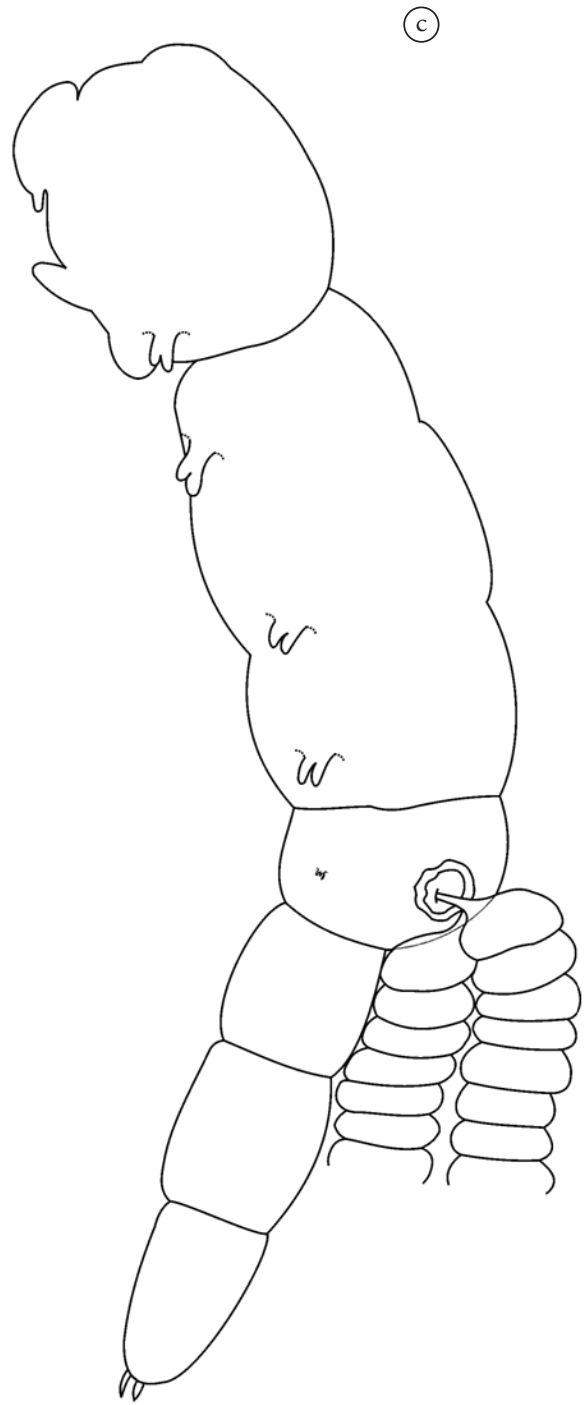

Figure 1. Female Lamproglena monodi Capart, 1944. a) Dorsal view; b) Ventral view; c) Lateral view.

Nevertheless, an analysis of the original description of $L$. monodi made by Capart (1944) and the redescription by Ibraheem and Izawa (2000) reveals some differences in relation to the specimens collected in Brazil. Capart (1944) described the antenna formed by four segments, but the antenna on the specimens observed in the present study only had three segments. In the redescription by Ibraheem and Izawa (2000), there is no mention of the number of segments. The number of setae and the position of the antennule were also different. In the description by Capart (1944), the basal segment has 20 setae, the distal segment has 10 setae and the antennule forms an angle in relation to the body; in the redescription by Ibraheem and Izawa (2000), the antennule has 23-24 setae, but the authors do not state how many setae each segment had. However, as shown in Figures 1e and 4, it was observed that the basal segment had 15 setae and the distal segment had eight setae. Capart reported that the basal segment of the maxilliped bore a papilla, but this papilla was not found on the specimens studied here, or in the illustration provided by Ibraheem and Izawa (2000). Moreover, the caudal ramus terminated with three papillae in the present specimens, four papillae in the specimens analyzed by Ibraheem and Izawa (2000) and three to four in the specimens analyzed by Capart (1944). Differences can be seen in the pairs of legs as well. In the description by Capart, the exopods terminated in one pair of setae and the endopods terminated in one pair of papillae. However, in the specimens analyzed in the present study, this number was variable, with exopods terminating in two, three or four setae and endopods terminating in two or four setae. Ibraheem and Izawa (2000) did not provide detailed comments on the legs. However, these are apparently intraspecies differences and are insufficiently characteristic for a new taxon to be proposed. 


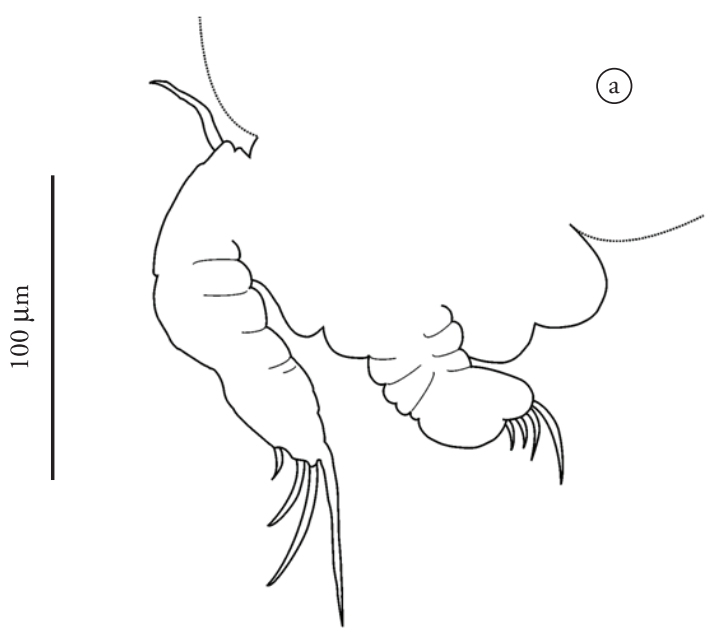

(c)

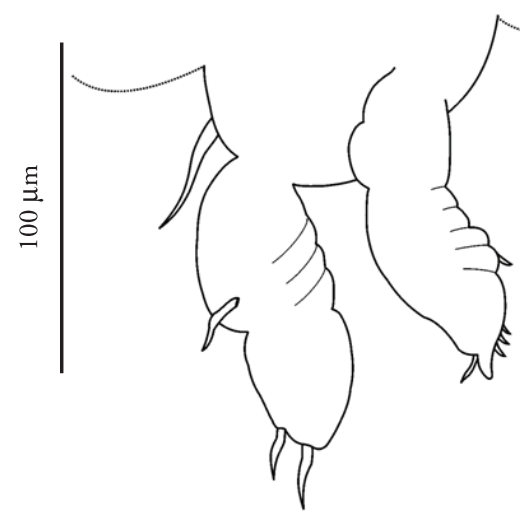

(e)
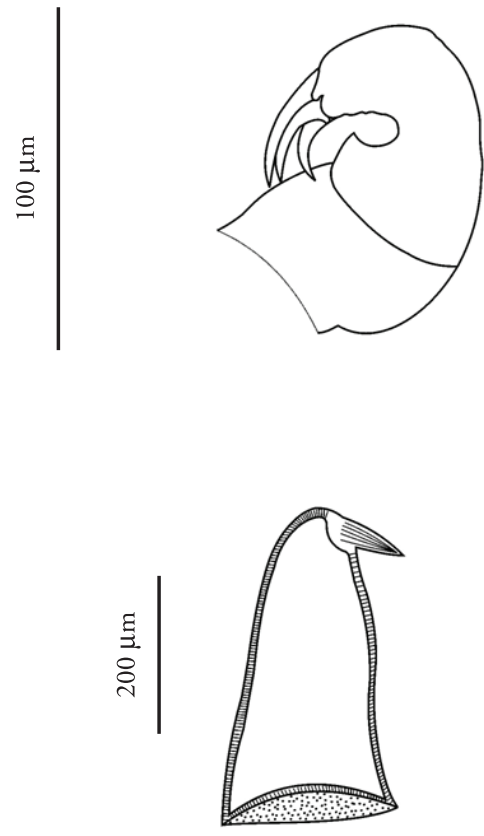

(g) (b)

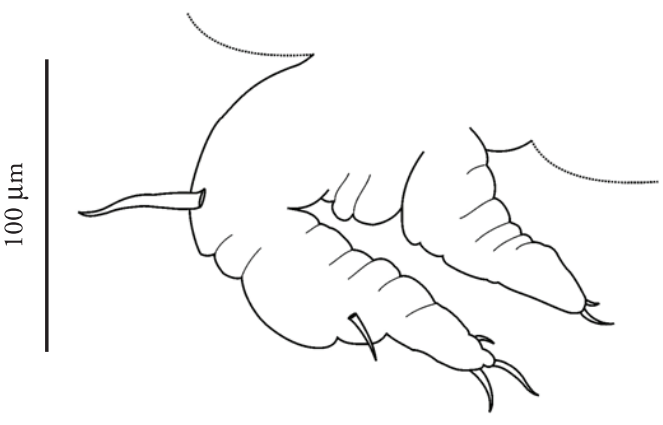

(d)

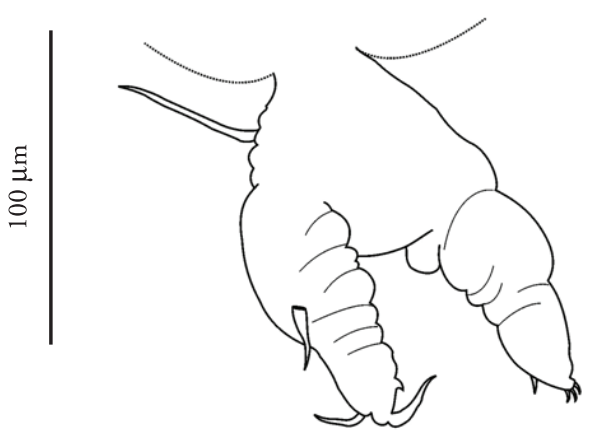

(f)
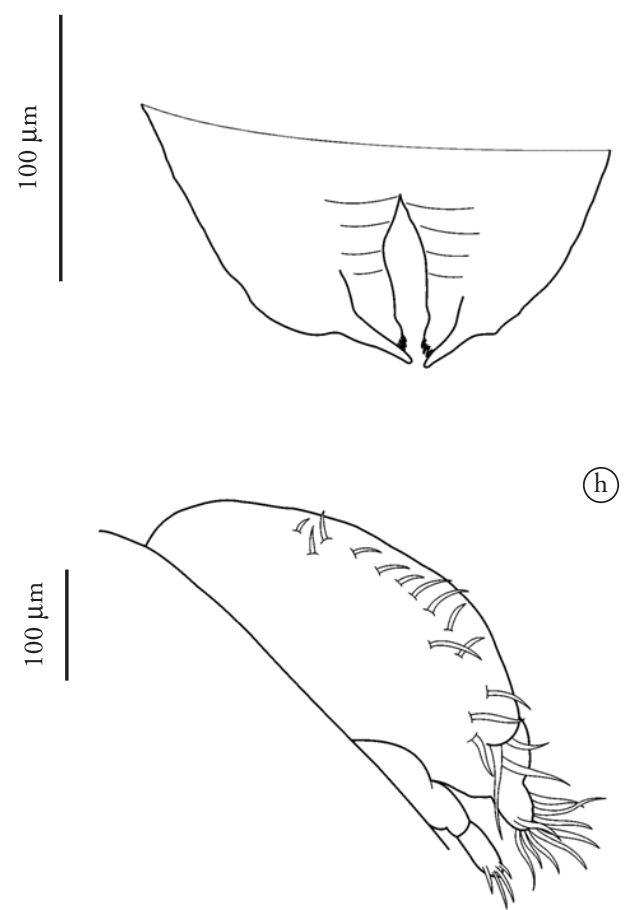

Figure 2. Female Lamproglena monodi Capart, 1944. a) First leg; b) Second leg; c) Third leg; d) Fourth leg; e) Maxilliped; f) Furcal rami; g) Maxilla; h) Antennule and antenna. 

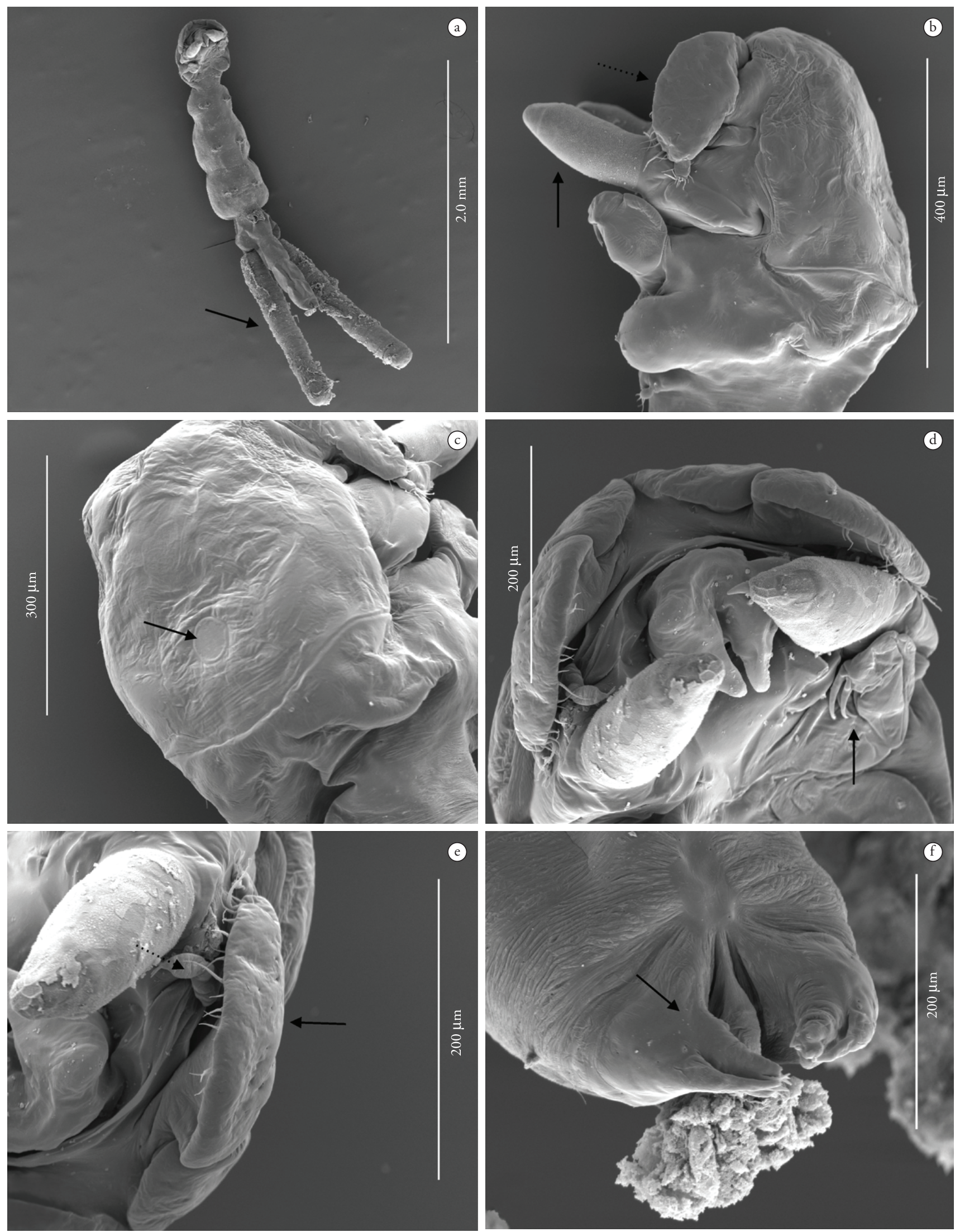

Figure 3. Scanning electron micrographs on female Lamproglena monodi Capart, 1944. a) Ventral view, showing the ovigerous sac (arrow); b) Lateral view, cephalothorax, showing the maxilla (arrow) and antennule (dashed arrow); c) Dorsal view, cephalothorax showing brand head (arrow); d) Ventral view, cephalothorax showing maxilliped (arrow); e) Detail of antennule (arrow) and antenna (dashed arrow); f) Furcal rami (arrow). 

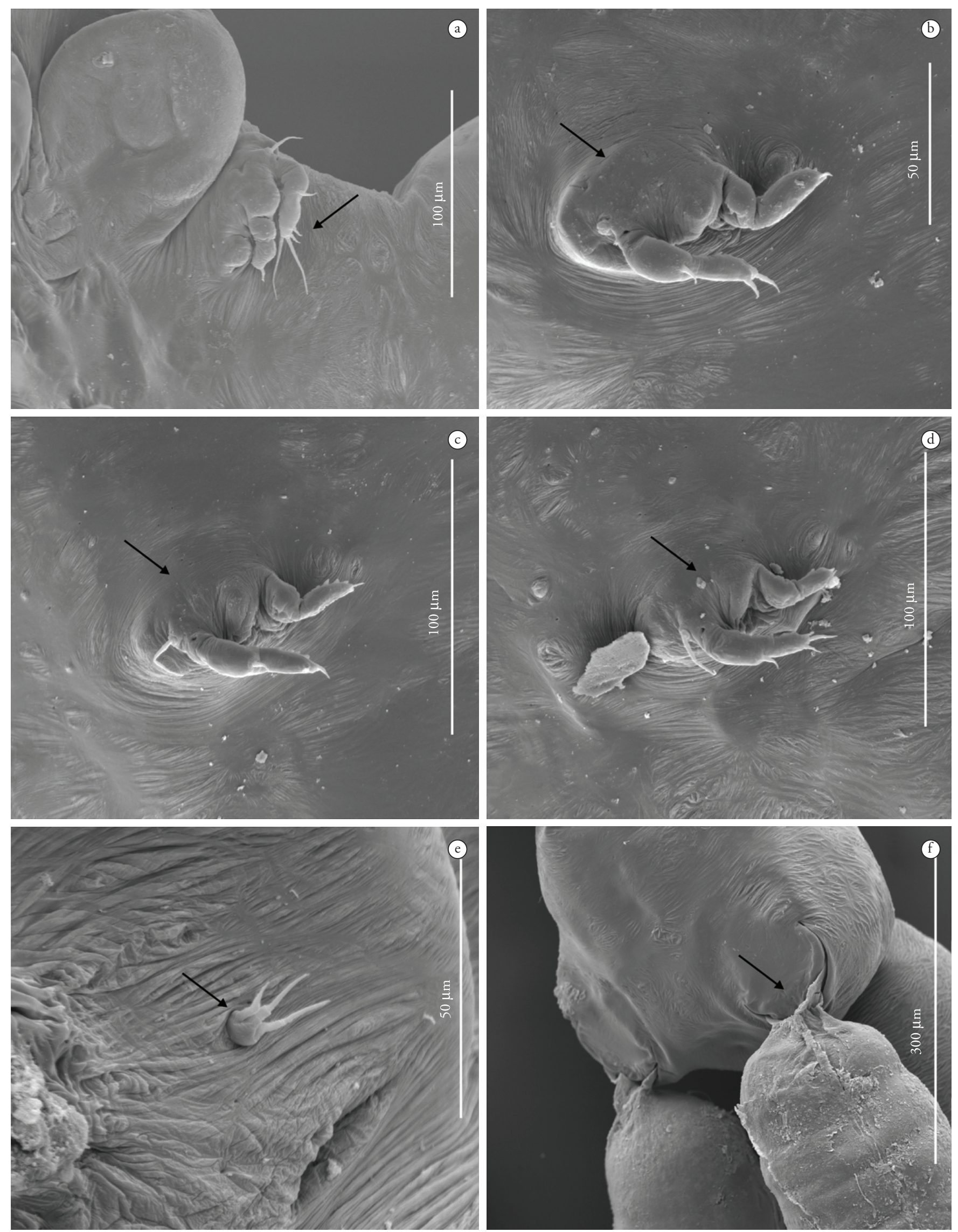

Figure 4. Scanning electron micrographs on female Lamproglena monodi Capart, 1944. a) First leg (arrow); b) Second leg (arrow); c) Third leg (arrow); d) Fourth leg (arrow); e) Fifth pair, rudimentary (arrow); f) Detail of insertion of ovigerous sac (arrow). 
Over recent decades, Brazil has stood out as the country with the largest number of non-native fish introduced into freshwater environments, including not only species imported from other countries, such as $T$. rendalli from Africa, but also native species transported from other Brazilian river basins, such as $C$. ocellaris and A. ocellatus from the Amazon River basin (BUCKUP; MENEZES, 2009). Introduction of exotic fish can lead to huge changes in the composition of the local fauna. These fish can alter the ecological conditions, thus affecting the reproduction, growth and development of native species as well as causing the disappearance of some species, a reduction in the abundance of juveniles and cases of hybridization (LATINI; PETRETE JUNIOR, 2004). There is also the problem of the introduction of parasites and diseases. The current geographical distribution of many parasites is substantially different from their original distribution, which can partially be attributed to human actions. Many species have been disseminated intra-continentally and inter-continentally. According to Hoffman (1970), many species of freshwater parasites have been established on other continents through the transportation of live fish, at times with catastrophic health consequences, especially when the parasites come into contact with new hosts. There is no doubt that the frequency and extent of invasions and introductions are on the rise, which can have a serious impact on native parasite communities, such as the case of the crustacean L. monodi, which was first described in the Congo, is often found in southeast Asia and has now been introduced into Brazil through the introduction of its host.

\section{Acknowledgements}

We would like to thank to the Electron Microscopy Center of the Institute of Biosciences, UNESP, Botucatu campus, for assistance regarding scanning electron microscopy. Rodney K. de Azevedo and Vanessa D. Abdallah were supported by postdoctoral fellowships from FAPESP. Maurício Laterça Martins and Reinaldo José da Silva were supported by research fellowships from $\mathrm{CNPq}$ and FAPESP, respectively, and José L. Luque was supported by a research fellowship from CNPq and by a grant from FAPERJ.

\section{References}

Azevedo RK, Abdallah VD, Luque JL. Acanthocephala, Annelida, Arthropoda, Myxozoa, Nematoda and Platyhelminthes parasites of fishes from the Guandu river, Rio de Janeiro, Brazil. Check List 2010; 6(4): 659-667.

Boxshall GA, Halsey SH. An Introduction to Copepod Diversity. London: The Ray Society; 2004.

Britski HA, Silimon KZS, Lopes BS. Peixes do Pantanal: manual de identificação. 2nd ed. Brasília: Embrapa Informação Tecnológica; 2007.

Buckup PA, Menezes A. Catálogo de peixes marinhos e de água doce do Brasil. [cited 2009 Ago. 10]. Available from: http://www.mnrj.ufrj.br/ catalogo.

Capart, A. Notes sur les copépodes parasites. III.- Copépodes parasites des poissons d'eau douce du Congo Belge. Bull Musée Royal d' Histoire Nat Belgique 1944; 20: 1-24.

Dedavid BA, Gomes CI, Machado G. Microscopia eletrônica de Varredura: Aplicaçôes e preparação de amostras. Porto Alegre: EDIPUCRS; 2007.

Hoffman GL. Intercontinental and transcontinental dissemination and transfaunation of fish parasites with emphasis on whirling disease (Myxosoma cerebralis). Am Fish Soc Spec Public 1970; 5: 69-81.

Ibraheem MH,Izawa K. On the morphology of Lamproglena monodi Capart, a parasitic copepod on the gills of Tilapia in Egypt. Zool Middle East 2000; 21: 103-108.

Latini AO, Petrere Junior M. Reduction of a native fish fauna by alien species: an example from Brazilian freshwater tropical lakes. Fish Manag Ecol 2004; 11: 71-79. http://dx.doi.org/10.1046/ j.1365-2400.2003.00372.x

Luque JL, Tavares LER. Checklist of Copepoda associated with fishes from Brazil. Zootaxa 2007; 1579: 1-39.

Mack RN, Simberloff D, Lonsdale WM, Evans H, Clout M, Bazzaz F. Biotic invasions: causes, epidemiology, global consequences, and control. Ecologic Appl 2000; 10: 689-710. http://dx.doi.org/10.1890/1051-076 1(2000)010[0689:BICEGC]2.0.CO;2

Martins ML, Azevedo TM, Ghiraldelli L, Bernardi N. Can the parasitic fauna on Nile tilapias be affected by different production systems? An Acad Bras Cienc 2010; 82(2): 493-500. http://dx.doi.org/10.1590/ S0001-37652010000200024

Taraschewski H. Hosts and parasites as aliens. J Helminthol 2006; 80(2): 99128. PMid:16768855. http://dx.doi.org/10.1079/JOH2006364 